\title{
Antibodies against Trichosporon beigelii in vaginal washings from asymptomatic women
}

\author{
G. QUINDOS, J. SCHNEIDER*, M. ALVAREZ, J. PONTON and R. CISTERNA
}

Departamentos de Microbiologia e Inmunologia and *Obstetricia y Ginecologia, Facultad de Medicina y Odontologia, Universidad del Pais Vasco-Euskal Herriko Unibertsitatea, Apartado 699, Bilbao, Spain

\begin{abstract}
Summary. Trichosporon beigelii was isolated from vaginal washings from three asymptomatic women. All three women had IgG or IgA anti-T. beigelii antibody titres $\geqslant 20$ when tested by an indirect immunofluorescence assay against the three strains isolated. Titres $\geqslant 160$ were found when each patient was tested against her own isolate. Patients with Candida albicans vulvovaginitis, or from whom C. albicans or Toruloposis glabrata was isolated from vaginal washings, or who had negative cultures for yeasts, had titres $\leqslant 20$.
\end{abstract}

\section{Introduction}

In the past decade awareness of the importance of infections caused by opportunistic fungi, including Trichosporon beigelii (syn. T. cutaneum) has increased. $T$. beigelii is usually non-pathogenic but it can cause a mild infection on hair shafts, known as white piedra. Since 1970, when it was first reported to be capable of causing systemic infection (Watson and Kallichurun, 1970), several reports have confirmed that it can cause deep-seated infections, mainly in surgical patients, intravenous drug abusers, bone marrow transplant recipients, and other immunosuppressed patients; Hoy et al., 1986; Walsh et al., 1986).

Despite the isolation of $T$. beigelii from vaginal swabs (Pritchard and Muir, 1985) and from patients with penile ulcers (Chapel et al., 1978) its pathogenic status in these locations is still unclear. Its presence may represent colonisation, asymptomatic infection, or a true infection with few symptoms, that may be attributed to another cause.

Here we report three cases in which $T$. beigelii was isolated from vaginal washings and attempt to elucidate the clinical relevance of the findings.

\section{Materials and methods}

\section{Subjects}

One hundred women attending a gynaecological clinic were investigated. They were examined clinically and signs of vulvitis, vaginitis and discharge were recorded as 0 (absent), 1 (moderate) and 2 (severe).

Received 11 Aug. 1988; revised version accepted 21 Sep. 1988.

\section{Vaginal samples}

Sterile saline $(10 \mathrm{ml})$ was instilled into the posterior fornix and aspirated. A washing of about $8 \mathrm{ml}$ was recovered from each patient. A gram-stained smear from the same location was examined for the presence of blastospores, mycelia or pseudomycelia. Each washing was centrifuged at $3000 \mathrm{rpm}$ for $10 \mathrm{~min}$ and the sediment was inoculated on to Sabouraud's dextrose agar (glucose $40 \mathrm{mg} / \mathrm{ml}$, peptone $10 \mathrm{mg} / \mathrm{ml}$, agar $20 \mathrm{mg} / \mathrm{ml}$ ) containing chloramphenicol $0.05 \mathrm{mg} / \mathrm{ml}$, and incubated at $37^{\circ} \mathrm{C}$ for $48 \mathrm{~h}$. If no growth had occurred the culture was then incubated at $25^{\circ} \mathrm{C}$ for a further 7 days. All the yeasts isolated were identified by the serum germ tube test and the API 20C AUX yeast identification system (API System SA, Montalieu Vercieu, France). Identification as $T$. beigelii was based on the following criteria: the presence of well-developed hyphae, pseudohyphae, and rectangular arthroconidia and blastoconidia; aerobic growth on Sabouraud's agar, producing smooth, shiny colonies that become cream-coloured and wrinkled after one week; absence of ability to ferment carbohydrates; assimilation of glucose, galactose, sucrose, maltose and lactose and hydrolysis of urea; assimulation of nitrate; and production of a film in broth (Kreger van Rij, 1984; Hoy et al., 1986).

\section{Immunoglobulin assays}

Immunofluorescence assays were done as previously described (Quindós et al., 1987). Briefly, $10 \mu \mathrm{l}$ of cell suspensions $\left(10^{6} / \mathrm{ml}\right)$ in phosphate buffered saline (PBS) of three different isolates of $T$. beigelii were applied to teflon-coated microscope slides; $1 \mathrm{ml}$ of vaginal washing supernate was lyophilised and resuspended in $0.5 \mathrm{ml}$ of PBS for study by immunofluorescence assay; fluoresceinconjugated goat anti-human immunoglobulins $A$ and $G$ were diluted 1 in 320 in PBS supplemented with Evans blue $0.001 \%$ and Tween $200.001 \%$ for use. 


\section{Results}

Of the 100 women included in this investigation, 23 were culture positive for yeasts. The organisms isolated as shown in the table. Microscopy of gramstained vaginal smears was found to be positive in only a reduced number $(18.2 \%)$ of the patients with a positive culture. It is noteworthy that the three isolations of $T$. beigelii were obtained on successive days. No common source of Trichosporon transmission by personnel or equipment was discovered and control cultures performed on them failed to grow Trichosporon.

The results obtained by immunofluorescence in the three patients with $T$. beigelii were compared with two control groups: patients with a positive growth of yeasts other than $T$. beigelii, and patients from whom yeasts were not grown (figure). Both $\operatorname{IgG}$ and $\operatorname{IgA}$ anti- $T$. beigelii antibody titres were raised (20-60) in $T$. beigelii carriers. Titres were highest when each patient was tested against her own $T$. beigelii isolate. Antibody titres were either much lower $(\leqslant 20)$ or absent in the control groups.
Table. Yeasts isolated from vaginal washings from 23 patients with positive cultures

Species Number of isolates

\begin{tabular}{lr}
\hline Candida albicans & 12 \\
Trichosporon beigelii & 3 \\
Torulopsis glabrata & 3 \\
Candida parapsilosis & 2 \\
Candida tropicalis & 1 \\
Candida krusei & 1 \\
Candida guilliermondii & 1 \\
$\quad$ Total & 23 \\
\hline
\end{tabular}

\section{Discussion}

Trichosporon beigelii is a common fungus associated with animals and has a wide distribution in nature (Kreger van Rij, 1984). In studies of immunocompromised patients, this organism has been demonstrated in samples of skin, sputum, stool and urine (Sandford et al., 1980). It is considered that the most likely portals of entry in

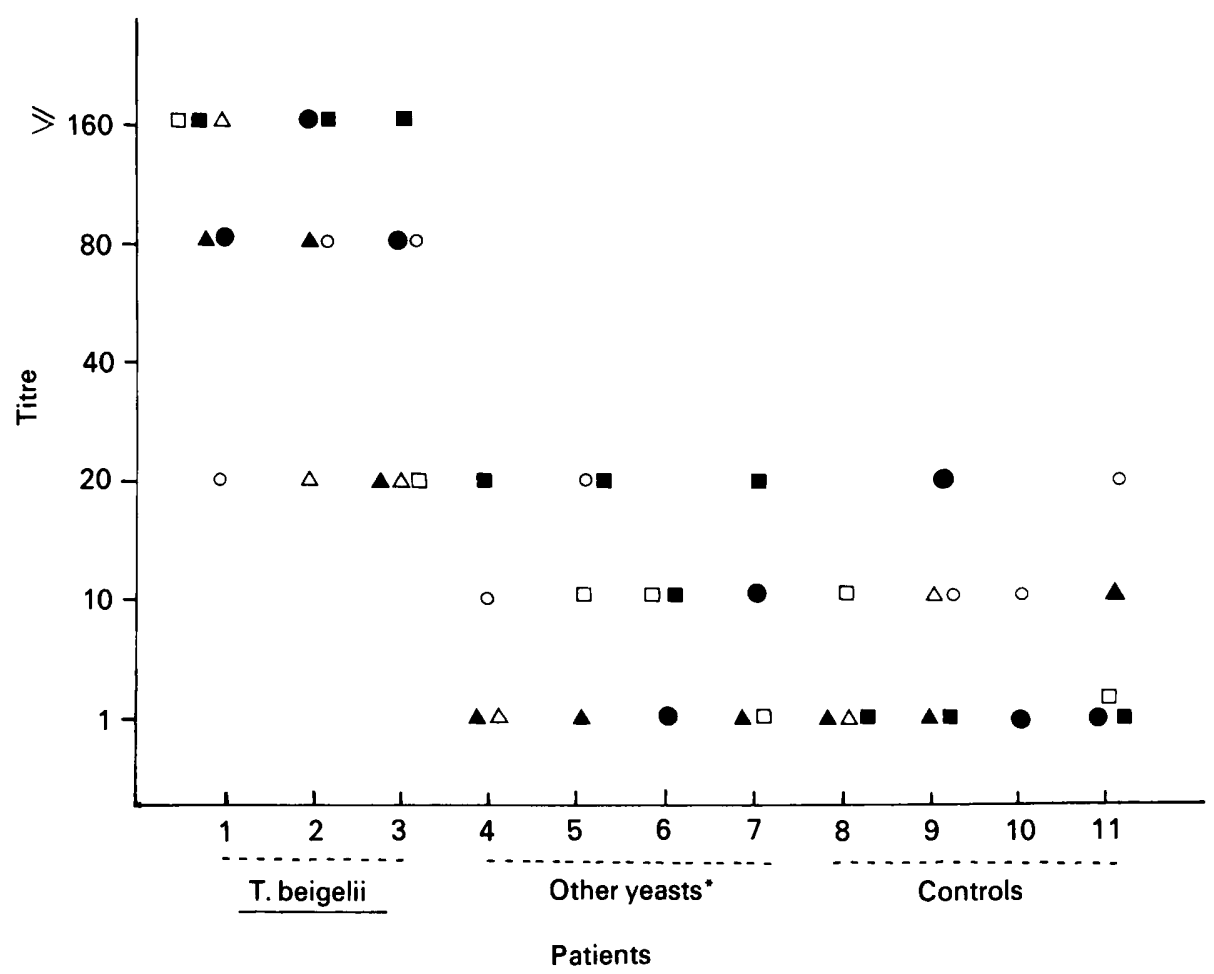

Figure. Antibody response of $\operatorname{IgA}(\triangle \square \bigcirc)$ and $\operatorname{IgG}$ antibodies $(\triangle \square \bigcirc)$ to $T$. beigelii observed in vaginal washings from 11 patients with and without $T$. beigelii isolation. $T$. beigelii strains used as antigens were isolated from patients $1(\mathbf{\Delta}, \triangle), 2(\boldsymbol{O}, \bigcirc)$ and $3(\square, \square) .{ }^{*}$ Other yeasts : patients 4 and 5 had $C$. albicans vulvovaginitis; C. albicans and $T$. glabrata were isolated from vaginal washings from patients 6 and 7 . 
disseminated trichosporonosis are the alimentary tract and the lungs (Walsh et al., 1986). Moreover, although the organism has been found to occur in high frequency in the rectal cultures of homosexual men (Torssander et al., 1985), infections with $T$. beigelii have not yet been reported in patients with AIDS.

Although $T$. beigelii has been previously reported in vaginal cultures (Pritchard and Muir, 1985), it is not considered a common coloniser of the vagina (Goldacre et al., 1979). However, the evidence of a humoral response in our subjects may suggest the presence of a subclinical infection. $T$. beigelii has been isolated from penile ulcers together with other micro-organisms (Chapel et al., 1978). This raises the question of its role as a secondary pathogen, as well as of its possible sexual transmission.

The isolations of $T$. beigelii took place during a short time period. This corroborates the findings of Walsh et al. (1986) who reviewed the cases of disseminated trichosporonosis of their hospital and

\section{REFERENCES}

Campbell C K, Payne A L, Teall A J, Brownell A, MacKenzie D W R 1985 Cryptococcal latex antigen test positive in patients with Trichosporon beigelii infection. Lancet 2: 4344.

Chapel T, Brown W J, Jeffries C, Stewart J A 1978 The microbiological flora of penile ulcerations. Journal of Infectious Diseases 137: 50-56.

Goldacre M J, Watt B, Loudon N, Milne L J R, Loudon J D O, Vessey M P 1979 Vaginal microbial flora in normal young women. British Medical Journal 1 : 1450-1453.

Hoy J, Hsu K-C, Rolston K, Hopfer R L, Luna M, Bodey G P 1986 Trichosporon beigelii infection: A review. Reviews of Infectious Diseases 8 : 959-967.

Kreger van Rij N J W (ed) 1984 The yeasts. A taxonomic study, 3rd edn. Elsevier, Amsterdam.

McManus E J, Bozdech M J, Jones J M 1985 Role of the latex agglutination test for cryptococcal antigen in diagnosing disseminated infections with Trichosporon beigelii. Journal of Infectious Diseases 151 : 1167-1169.

McManus E J, Jones J M 1985 Detection of a Trichosporon beigelii antigen cross-reactive with Cryptococcus neoformans capsular polysaccharide in serum from a patient with observed that four of 15 occurred during the same month.

Although others have found cross reactions with Cryptococcus neoformans (Campbell et al., 1985; MacManus and Jones, 1985; MacManus et al., 1985 ), in this study there was no cross reactivity with $C$. albicans. The antibody titres to $T$. beigelii found in the vaginal washings of our control patients (both asymptomatic and with candida vaginitis) were very low or absent. These findings seem to contradict those reported by Matthews $e t$ al. (1986) who found anti-T. beigelii antibodies in the sera of all patients without clinical evidence of $T$. beigelii infection. Further investigations are required to determine the pathogenic significance of $T$. beigelii in the human vagina.

We thank Professor D. W. R. MacKenzie (Mycological Reference Laboratory) for reviewing the manuscript, the Medical Illustration Department, Central Public Health Laboratory, Colindale, London, for the graphic work, and Joseba Bikandi for his technical assistance.

disseminated Trichosporon infection. Journal of Clinical Microbiology 21 : 681-685.

Matthews R C, Burnie J P, Fox A, Woods M, Tabaqchali S 1986 Immunoblot analysis of the serological response in invasive Trichosporon beigelii and Blastoschizomyces capitatus infection. Journal of Clinical Microbiology 23: 395-397.

Pritchard R C, Muir D B 1985 Trichosporon beigelii: survey of isolates from clinical material. Pathology 17: 20-23.

Quindós G, Pontón J, Cisterna R 1987 Detection of antibodies to Candida albicans germ-tube in the diagnosis of systemic candidiasis. European Journal of Clinical Microbiology 6: 142-146.

Sandford G R, Merz W G, Wingard J R, Charache P, Saral R 1980 The value of fungal surveillance cultures as predictors of systemic fungal infections. Journal of Infectious Diseases 142: 503-509.

Torssander J, Carlsson B, Von Krough G 1985 Trichosporon beigelii: Increased occurrence in homosexual men. Mykosen 28: $355-356$.

Walsh T J, Newman K R, Moody M, Wharton R C, Wade J C 1986 Trichosporonosis in patients with neoplastic disease. Medicine 65 : 268-279.

Watson K C, Kallichurum S 1970 Brain abscess due to Trichosporon cutaneum. Journal of Medical Microbiology 3: 191-193. 